\title{
Review
}

\section{Antioxidant Activity of Natural Hydroquinones}

\author{
Rosa M. Giner, José Luis Ríos and Salvador Máñez *
}

check for updates

Citation: Giner, R.M.; Ríos, J.L.; Máñez, S. Antioxidant Activity of Natural Hydroquinones. Antioxidants 2022, 11, 343. https://doi.org/ 10.3390/antiox11020343

Academic Editors: Stefania Pizzimenti, Giuliana Muzio and Giuseppina Barrera

Received: 25 January 2022 Accepted: 7 February 2022 Published: 9 February 2022

Publisher's Note: MDPI stays neutral with regard to jurisdictional claims in published maps and institutional affiliations.

Copyright: (C) 2022 by the authors. Licensee MDPI, Basel, Switzerland. This article is an open access article distributed under the terms and conditions of the Creative Commons Attribution (CC BY) license (https:// creativecommons.org/licenses/by/ $4.0 /)$.
Departament de Farmacologia, Facultat de Farmàcia, Universitat de València, Av. Vicent Andrés Estellés s/n, 46100 Burjassot, Spain; rmginer@uv.es (R.M.G.); riosj1@uv.es (J.L.R.)

* Correspondence: manez@uv.es; Tel.: +34-686-088-835

\begin{abstract}
Secondary metabolites derived from hydroquinone are quite rare in nature despite the original simplicity of its structure, especially when compared to other derivatives with which it shares biosynthetic pathways. However, its presence in a prenylated form is somewhat relevant, especially in the marine environment, where it is found in different algae and invertebrates. Sometimes, more complex molecules have also been identified, as in the case of polycyclic diterpenes, such as those possessing an abietane skeleton. In every case, the presence of the dihydroxy group in the para position gives them antioxidant capacity, through its transformation into para-quinones.This review focuses on natural hydroquinones with antioxidant properties referenced in the last fifteen years. This activity, which has been generally demonstrated in vitro, should lead to relevant pharmacological properties, through its interaction with enzymes, transcription factors and other proteins, which may be particularly relevant for the prevention of degenerative diseases of the central nervous system, or also in cancer and metabolic or immune diseases. As a conclusion, this review has updated the pharmacological potential of hydroquinone derivatives, despite the fact that only a small number of molecules are known as active principles in established medicinal plants. The highlights of the present review are as follows: (a) sesquiterpenoid zonarol and analogs, whose activity is based on the stimulation of the Nrf2/ARE pathway, have a neuroprotective effect; (b) the research on pestalotioquinol and analogs (aromatic ene-ynes) in the pharmacology of atherosclerosis is of great value, due to their agonistic interaction with $\operatorname{LXR} \alpha$; and (c) prenylhydroquinones with a selective effect on tyrosine nitration or protein carbonylation may be of interest in the control of post-translational protein modifications, which usually appear in chronic inflammatory diseases.
\end{abstract}

Keywords: alkyl phenolics; antioxidant; hydroquinones; marine natural products; meroterpenoids; reactive oxygen species; secondary metabolites

\section{Introduction}

Hydroquinone (1,4-dihydroxybenzene, Figure 1) is a very simple phenolic structure that appears in secondary plant metabolites present in species with different phylogenies, with the most prominent taxa being found in Ericales, Lamiales and Asterales. However, such compounds are present in brown and green algae and in bacteria and a high number of marine invertebrate organisms, such as sponges, cnidaria, and ascidians.<smiles>Oc1ccc(O)cc1</smiles>

(a)

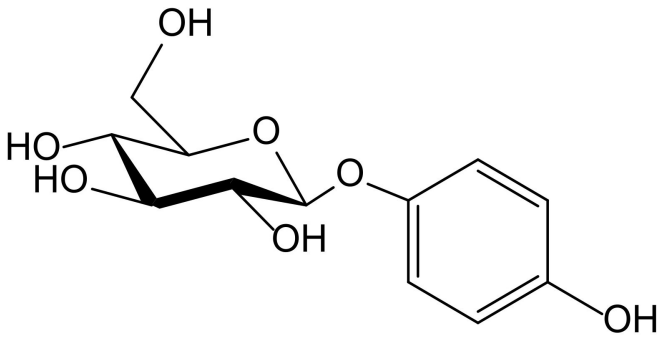

(b)
Figure 1. Chemical structures of hydroquinone (a) and arbutin (b). 
Although an exhaustive study of the biosynthetic origin of hydroquinones is outside the scope of this review, it is perhaps pertinent to mention a few general lines. At first, it must be stated that the $p$-dihydroxybenzene ring comes from the shikimate pathway, from chorismate to $p$-hydroxybenzoate (PHB), by the effect of chorismate lyase, then by the subsequent transformation into hydroquinone by PHB-1-hydroxylase, as it has been analyzed in detail in the process of heterologous production of arbutin, also termed arbutoside (4-hydroxyphenyl-1-O- $\beta$-D-glucopyranoside, Figure 1), in Yarrowia [1]. The transformation of homogentisate into gentisate and the decarboxylation of gentisate into hydroquinone constitute alternative, less frequent routes, as occurs in sponge prenylhydroquinones [2]. Secondly, it should be noted that many of the natural hydroquinones have a terpenoid part, which is sometimes very bulky, which is why they are considered part of the complex group of meroterpenoids. As regards the way in which the aromatic ring is integrated into these types of molecules, in most cases it is a simple conjunction driven by prenyl transferases, but on other occasions such a ring is a part of its own terpenoid skeleton and, therefore, the benzene ring is generated by cyclic dehydrogenations.

Hydroquinone derivatives, when both hydroxyls are free, are easily transformed, in the presence of oxygen or metal cations, into $p$-quinones. The transit between the phenolic (reduced) and quinonic (oxidized) forms involves the participation of $2 \mathrm{H}^{+}$and $2 \mathrm{e}^{-}$, and the redox potential of the process is markedly influenced by the $\mathrm{pH}$ of the medium and the nature of the solvent. For the purposes of biological activity, it is important to note that the aforementioned reaction is carried out in two steps, with the formation of an intermediate semiquinone, a compound endowed with a certain capacity to generate reactive oxygen species (ROS), which is very relevant to possible cellular toxicity [3]. For decades, this concept has been crucial in the field of mitochondrial biochemistry since the functioning of the complexes I and III of the respiratory chain is based on this reaction, materialized by the pair ubiquinone/ubiquinol (coenzyme Q), as was described by Frederick Crane [4].

On the basis of this set of concepts, the present review tries to systematize the studies on the antioxidant effects of natural hydroquinones by analyzing the most important papers published during the 2005-2020 period, with some temporal extension, when applicable. The organization of this manuscript is based on two criteria: the analytical methodology concerning the oxidative processes and the chemical structure of the active principles.

\section{Free Radical Scavenging and Related Antioxidant Chemical Analysis}

\subsection{Simple Hydroquinones}

In a study on the oxygen free radical scavenging properties of 70 Chinese medicinal plants, Rhodiola sacra (Prain ex Raym.-Hamet) S.H. Fu (Crassulaceae) was one of the most active, along with other species belonging to the well-known genera Areca, Juglans, Paeonia and Psychotria. Further research on the principles of the roots of $R$. sacra determined that hydroquinone exerted a quite moderate activity as a scavenger of the superoxide anion $\left(\mathrm{O}_{2}{ }^{\bullet-}\right)$ generated by a hypoxanthine/xanthine oxidase system and measured by spin trapping with 5,5-dimethylpyrroline- $N$-oxide $\left(\mathrm{IC}_{50} 72 \mu \mathrm{M}\right)$. Moreover, some other common catechins and phenolic acids, as well as, to a lesser extent, the cyanogenic glycoside heterodendrin, participate in this effect, which was primarily observed in both methanolic and aqueous extracts of the crude drug. Provided that their $\mathrm{IC}_{50}$ values were ranged $1.5-4.0 \mu \mathrm{M}$, the principles responsible for the antioxidant effect of the $R$. sacra root extracts seem to be gallic acid and its catechin esters found therein [5].

The aerial parts of Origanum majorana L. (Lamiaceae) were extracted with boiling water for $2 \mathrm{~h}$, and the aqueous extract fractionated with hexane and ethyl acetate. From the ethyl acetate extract, the following phenolic compounds were purified and identified: hydroquinone, arbutin, rosmarinic acid, 5,6,3'-trihydroxy-7,8, $4^{\prime}$-trimethoxyflavone, and 5,7,3'-trihydroxy-4'-methoxyflavanone (hesperetin). The antioxidant activity was determined by carrying out two tests of free radical scavenging: 1,1-diphenyl-2-picrylhydrazylradical (DPPH ${ }^{\bullet}$ ) assay and 2,2'-azinobis-(3-ethylbenzothiazoline-6-sulfonic acid) radical cation $\left(\mathrm{ABTS}^{\bullet+}\right)$, and the ferric reducing antioxidant power (FRAP) assay, with potassium 
ferricyanide. Among these compounds, hydroquinone ( $0.054 \%$ of plant dry weight) was the most potent in both tests, whereas its glucoside, arbutin ( $0.039 \%$ of plant dry weight), was the least potent. However, both hydroquinonic principles differed compared to the rest, for their highest anti-proliferative potency on tumoral C- 6 cells. In order to get an appropriate picture of the relative influence of the different phenolic principles on the effects of O. majorana as a whole, some comparisons may be quite useful: the $\mathrm{IC}_{50}$ of hydroquinone in the DPPH test was $17.44 \mu \mathrm{M}$, whereas that of hesperetin (3.81\% of plant dry weight) was $21.44 \mu \mathrm{M}$. Considering these data, the contribution of this last flavonoid to the plant activity, as a free radical scavenger agent, should be circa 20 times that of hydroquinone [6].

From the aerial parts of Mikania micrantha Kunth (Compositae), Dong et al. identified fourteen phenolics, among them hydroquinone itself and the new hydroquinone derivative, benzyl 5-O- $\beta$-D-glucopyranosyl-2,5-dihydroxybenzoate (Figure 2). Both compounds were tested as potential antioxidant principles in $\mathrm{ABTS}^{\bullet+}$ and $\mathrm{DPPH}^{\bullet}$ radical scavenging assays, and in the FRAP assay, with L-ascorbic acid as a reference compound. In the case of the glucoside, when tested on the ABTS assay, it showed a scavenger concentration $50 \%$ (SC $\mathrm{S}_{50}$ ) of $0.31 \mu \mathrm{M}$, the highest potency among the tested compounds, including hydroquinone (SC $504.57 \mu \mathrm{M}$ ) and ascorbic acid (SC $5010.45 \mu \mathrm{M})$. In the FRAP assay, it also displayed interesting activity with a reducing capacity of $0.34 \mathrm{mmol} / \mathrm{g}$, clearly better than the ones obtained for hydroquinone $(8.77 \mathrm{mmol} / \mathrm{g})$ and ascorbic acid $(11.32 \mathrm{mmol} / \mathrm{g})$. However, the glycoside had no effect in the DPPH test $\left(\mathrm{SC}_{50}>100 \mu \mathrm{M}\right)$, whereas hydroquinone $\left(\mathrm{SC}_{50}\right.$ $31.96 \mu \mathrm{M})$ showed a potency similar to that of ascorbic acid $\left(\mathrm{SC}_{50} 39.48 \mu \mathrm{M}\right)$. The authors proposed this compound for future studies on chronic diseases in which free radicals and ROS are implicated, such as atherosclerosis, angiocardiopathy, and cancer [7].

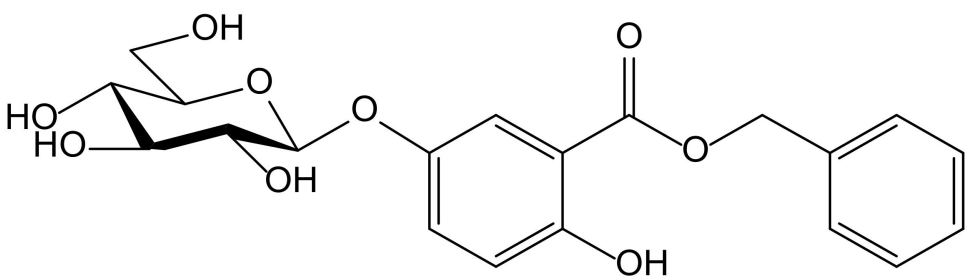

Figure 2. Chemical structure of benzyl 5-O- $\beta$-D-glucopyranosyl-2,5-dihydroxybenzoate isolated from Mikania micrantha.

In a detailed work on the phenolic compounds of both raw and bee-processed corn pollen obtained from hives in the province of Nan (Thailand), hydroquinone and a glycoside of the flavone apigenin were described as the most powerful antioxidants therein. Nevertheless, the nuclear magnetic resonance spectroscopic data that might justify the identification of hydroquinone are inconclusive and, therefore, the actual presence of this molecule in the analyzed extracts seems to be untrue [8].

The hydroquinone trisaccharide, 4-hydroxyphenyl- $\beta$-D-glucopyranosyl- $(1 \rightarrow 6)-\beta$ - $D$ glucopyranosyl-(1 $\rightarrow 6)-\beta$-D-glucopyranoside (Figure 3$)$, together with some other closely related hydroxybenzene glycosides, was isolated as a minor from the germs of wheat (Triticum aestivum L., Poaceae). That compound showed activity in the so called Trolox equivalent antioxidant capacity (TEAC) test, which consists of the oxidation of ABTS to form the free radical $\mathrm{ABTS}^{\bullet+}$. The capture of $\mathrm{ABTS}^{\bullet+}$ was monitored, in comparison to that produced by 6-hydroxy-2,5,7,8-tetramethylchroman-2-carboxylic acid (Trolox). Under such conditions, the hydroquinone triglucoside showed a softly growing effect along $5 \mathrm{~min}$, with potency 1.12 times higher than that of Trolox. The authors managed to explain how, in previous papers, it was reported that an increase of the number of sugars in simple hydroquinones weakened the antioxidant activity in the DPPH scavenging test. This fact, which certainly does not occur with $\mathrm{ABTS}^{\bullet+}$, probably correlates with the steric hindrance affecting $\mathrm{DPPH}^{\bullet}$ radical [9]. 


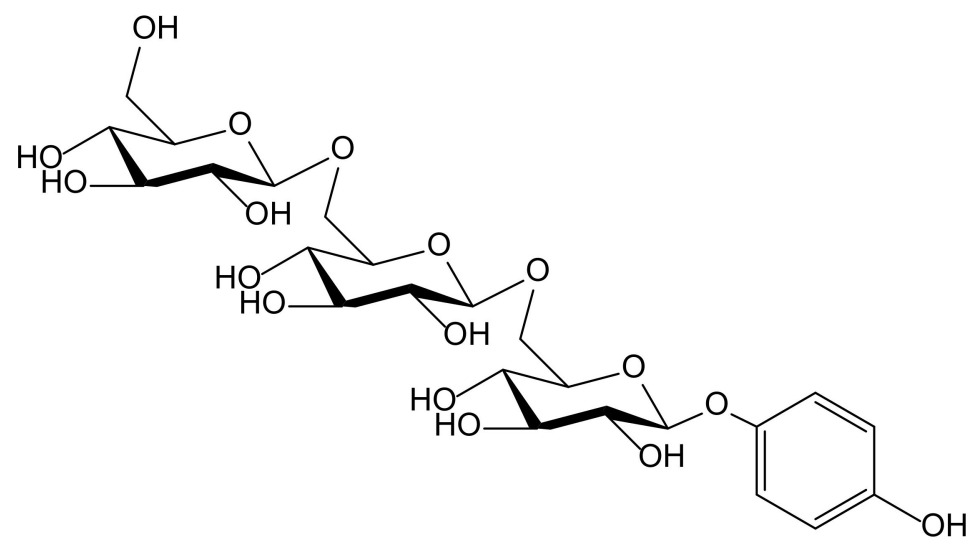

Figure 3. Chemical structure of 4-hydroxyphenyl- $\beta$-D-glucopyranosyl-( $1 \rightarrow 6)-\beta$-D-glucopyranosyl$(1 \rightarrow 6)$ - $\beta$-D-glucopyranoside isolated from Triticum aestivum.

Hydroquinone and its 6" $-O$-caffeoylglucoside (robustaside B, Figure 4) were described in the leaves of Cnestis ferruginea Vahl ex DC. (Connaraceae), a medicinal plant native to western tropical Africa, known for its laxative and antimicrobial activity. Both phenolic principles were characterized as antioxidants when rat mitochondria were treated with $\mathrm{Fe}^{2+} /$ ascorbate to induce membrane lipid peroxidation. At the concentrations tested (0.05-1.0 mM), there was no concentration-response relationship since the percentages of inhibition of the production of thiobarbituric acid reacting species (TBARS) only varied from 81.0 to 86.5 . It is clear that some experiments working in the $\mu \mathrm{M}$, even $\mathrm{nM}$, range would have been advisable. Furthermore, hydroquinone and robustaside B caused the rat liver mitochondria permeability transition pore to open, although they acted in the opposite way when such opening was caused by an increase in calcium. In agreement with the latter effect, it should be noted that release of calcium provokes deregulation of membrane function, mitochondrial swelling, and cell apoptosis [10].<smiles>O=C(/C=C/c1ccc(O)c(O)c1)OCC1O[C@H](O)[C@H](O)[C@H](O)[C@H](O)[C@H]1Oc1ccc(O)cc1</smiles>

Figure 4. Chemical structure of robustaside B isolated from Cnestis ferruginea.

\subsection{Terpenoid Hydroquinones}

Of the eighteen compounds isolated from the aerial parts of Origanum dubium Boissin fact, a synonym of O. majorana (Lamiaceae) — collected in Cyprus, three were identified as simple hydroquinone glycosides: arbutin, seguinoside $B$, and osmantolide, and three more as monoterpenoid hydroquinone glycosides: thymoquinol-2-O- $\beta$-D-glucopyranoside, and thymoquinol-5-O- $\beta$-D-glucopyranoside (Figure 5). Osmantolide seems to be the principal active compound in the DPPH test since it showed, at $0.1 \mathrm{mM}$, a $63 \%$ and $65 \%$ inhibition at 20 and $60 \mathrm{~min}$, respectively, whereas the other compounds assayed did notexceed $30 \%$ at similar concentrations. For the inhibition of linoleic acid peroxidation, the authors used $2,2^{\prime}$-azobis(2-amidinopropane) (ABAP) as a free radical initiator, and Trolox was used as a standard. Thymoquinol-5-O- $\beta$-D-glucopyranoside $(85 \%)$ and osmantolide $(77 \%)$ gave the highest inhibitory effects, whereas the rest of the compounds did notexceed $40 \%$. The 
authors included some experimental data related to potential anti-inflammatory activity, but they did not perform any tests of inflammation [11].

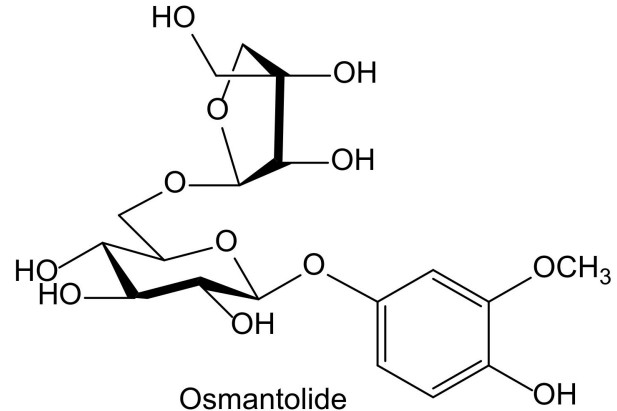<smiles>Cc1cc(O)c(C(C)C)cc1O[C@@H]1O[C@@H]2O[C@@H]1[C@@H](CO)C(O)C2O</smiles>

Thymoquinol-2-O- $\beta$ - D-glucopyranoside

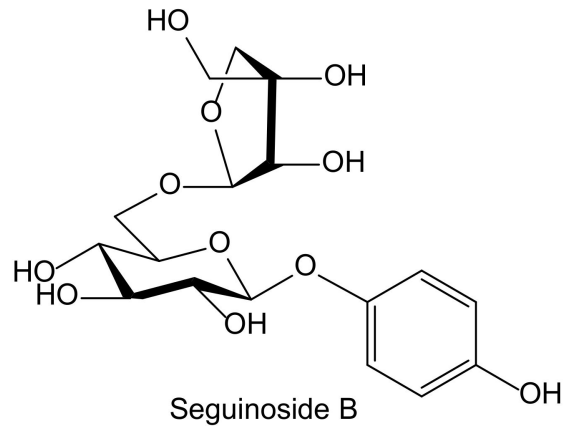<smiles>Cc1cc(OC2O[C@H](C(O)CO)C(O)C(CO)[C@@H]2O)c(C(C)C)cc1O</smiles>

Thymoquinol-5-O- $\beta$ - D-glucopyranoside

Figure 5. Chemical structures of hydroquinones isolated from Origanum majorana.

Yamaguchi et al. isolated and identified the new 1-O-methyl-2-[(2'E)-diprenyl]hydroquinone together with the known $\left(2^{\prime} \mathrm{E}\right)-1^{\prime}$-oxo-diprenylhydroquinone and $\left(2^{\prime} Z\right)$ $1^{\prime}$-oxo-diprenylhydroquinone (Figure 6) from the fruits of Piper crassinervium Kunth (Piperaceae). They evaluated the antioxidant potential of these geranyl-hydroquinone derivatives through their capacity to inhibit both $\mathrm{DPPH}^{\bullet}$ radical scavenging and luminol chemiluminescence, induced by ABAP as a peroxyl radical source. Their protective effects against lipid peroxidation induced by $\mathrm{Fe}^{3+} /$ EDTA and ascorbic acid were assessed in liposomes of phosphatidylcholine. These prenylated hydroquinones exhibited substantial radical scavenger capacities in the $\mathrm{DPPH}^{\bullet}$, chemiluminescence, and lipid peroxidation tests. The new natural compound showed higher potency $\left(\mathrm{IC}_{50} 14.5 \mu \mathrm{M}\right)$ for lipid peroxidation than the known ones (6.2 and 6.3, with $\mathrm{IC}_{50} 26.4$ and $63.1 \mu \mathrm{M}$, respectively) but lower potency than Trolox $\left(\mathrm{IC}_{50} 2.6 \mu \mathrm{M}\right)$. Among these last hydroquinones, the $E$ isomer was more efficient than $Z$ isomer, probably due to its better insertion in the liposome [12].

Algae are another source of hydroquinones and related compounds. Fish et al. isolated fourteen meroterpenoids from the brown alga Cystoseira crinita Duby (Sargassaceae). Eight of them were new prenyl-toluquinols, a class of methylhydroquinone compounds, with six of them being tetraprenyl derivatives and two triprenyl derivatives (Figure 7). Furthermore, some additional known, related molecules were identified. All these compounds were tested for their antioxidant properties in the DPPH and TBARS tests. In the DPPH test, the hydroquinone derivatives gave the highest radical-scavenging effects, with percentages of scavenging activities between 93 and 97\%, similar to those of $\alpha$-tocopherol (95\%), all of them at $230 \mu \mathrm{M}$. At lower concentrations, only three compounds had remarkable activity, with scavenging activities of $80 \%$ at $58 \mu \mathrm{M}$ and $30 \%$ at $23 \mu \mathrm{M}$. In the TBARS assay of peroxidation of linolenic acid methyl ester, all hydroquinones had similar effect to that of the control, being $69 \%$ for butylated hydroxytoluene (BHT) and $73 \%$ for $\alpha$-tocopherol. In the TEAC test, they showed activities between 13\% and 59\% that of $\alpha$-tocopherol, whereas in the photochemiluminescence test the highest values were $41 \%$ and $112 \%$ that of $\alpha$-tocopherol, which indicated that some of these compounds had a relevant radicalscavenging power. Despite the high number and variety of the analyzed compounds, it has not been possible to establish either the influence of the radicals nor other structural 
activity relationships; so, it was considered that the only chemical group of interest as an antioxidant is hydroquinone [13].

In a screening for anti-oxidative substances, Kamagai et al. [14] found relevant activity of the methanol extract of the brown alga Dictyopteris undulata Holmes (Dictyotaceae) on the DPPH test. After a bioassay-guided fractionation, they isolated five sesquiterpenoids, three of them hydroquinone derivatives: isozonarol, isozonarone, and chromazonarol (Figure 8). These compounds were tested using the same protocol, and the authors observed that the $\mathrm{DPPH}^{\bullet}$ radical scavenging activity was highest for isozonarol, with an $\mathrm{EC}_{50}$ of $71 \mu \mathrm{M}$, similar to that obtained for $\alpha$-tocopherol used as a positive control. Isozonaroneand chromazonarol gave values of $145 \%$ and $121 \%$ of inhibition, respectively. In this case, it is clear that hydroquinone is the active center with efficient scavenging properties against ROS $[15,16]$. This relevant effect vanishes when the $p$-hydroquinone structure disappears or is blocked with different radicals. It was observed that other isolated sesquiterpenoids had no activity because they did not include the hydroquinone center in their molecules. As a conclusion, the authors proposed specific studies for establishing the potential antiinflammatory and neuroprotective effects due to the structural similarity with zonarol, the activity of which was previously reported [14]. The latter compound was not tested in the DPPH test, but it was assayed on the nuclear factor-erythroid 2-related factor 2 antioxidantresponsive element (Nrf2/ARE) pathway for its potential neuroprotective effects. Indeed, zonarol protected HT22 hippocampal neuronal cells against oxidative stress, through activationof the Nrf2/ARE pathway. This compound can be considered a pro-electrophilic drug because the hydroquinone group can be oxidized to a quinone. The authors concluded that zonarol could be considered as an effective neuroprotective agent against oxidative insults, and mitochondrial dysfunction, and could be lead drug for the treatmentof chronic neurodegenerative diseases associated with oxidative stress [17].<smiles>COc1ccc(O)cc1CC=C(C)CCC=C(C)C</smiles>

1-O-Methyl-2-[(2'E)-diprenyl]-hydroquinone<smiles>CC(C)=CCC/C(C)=C/C(=O)c1cc(O)ccc1O</smiles>

$\left(2^{\prime} E\right)-1^{\prime}$-Oxo-diprenylhydroquinone<smiles>CC(C)=CCC/C(C)=C/C(=O)c1cc(O)ccc1O</smiles>

(2'Z)-1'-Oxo-diprenylhydroquinone

Figure 6. Chemical structures of hydroquinones isolated from Piper crassinervium. 
<smiles>[R]c1cc(O)cc(C)c1O</smiles>

$$
\mathrm{R}=
$$<smiles>C/C=C(\C)CC(=O)/C=C(\C)CC/C=C(\C)CCC=C(C)CO</smiles>

2-[(2'E,6'E,10'E,14'Z)-5'-oxo-16'-hydroxy-tetraprenyl)]-6-methylhydroquinone<smiles>C/C=C(\C)CC(=O)/C=C(/C)CC/C=C(\C)CC/C=C(/C)CO</smiles>

2-[(2'E,6'Z,10'E,14'Z)-5'-oxo-16'-hydroxy-tetraprenyl)]-6-methylhydroquinone<smiles>CC=C(C)CC(=O)C=C(C)CCC=C(C)CC(O)C=C(C)C</smiles>

2-[(2'E,6'E,10'E)-5'-oxo-13'-hydroxyl-tetraprenyl)]-6-methylhydroquinone<smiles>C/C=C(\C)CC(=O)/C=C(/C)CC/C=C(\C)CC(O)C=C(C)C</smiles>

2-[(2'E,6'Z,10'E)-5'-oxo-13'-hydroxyl-tetraprenyl)]-6-methylhydroquinone<smiles>C/C=C(\C)CC(=O)/C=C(\C)CC/C=C(\C)CCC=C(C)C</smiles>

2-[(2'E,6'E,10'E)-5'-oxo-tetraprenyl)]-6-methylhydroquinone<smiles>C/C=C(\C)CC(=O)/C=C(/C)CC/C=C(\C)CCC=C(C)C</smiles>

2-[(2'E,6'Z,10'E)-5'-oxo-tetraprenyl)]-6-methylhydroquinone<smiles>C/C=C(\C)CC(=O)/C=C(\C)CCC=C(C)C</smiles>

2-[(2'E,6'E)-5'-oxo-triprenyl)]-6-methylhydroquinone<smiles>C/C=C(\C)CC(=O)/C=C(/C)CCC=C(C)C</smiles>

2-[(2'E,6'Z)-5'-oxo-triprenyl)]-6-methylhydroquinone

Figure 7. Chemical structures of the new hydroquinones isolated from Cystoseiracrinita. 
<smiles>C=C1CC[C@]2(P)C(C)(C)CCC[C@]2(C)[C@H]1Cc1cc(O)ccc1O</smiles>

Zonarol<smiles>CC1=CC[C@]2([18CH3])C(C)(C)CCC[C@]2(C)[C@H]1CC1=CC(=O)C=CC1=O</smiles><smiles>CC1=CC[C@]2(C)C(C)(C)CCC[C@]2(C)[C@H]1Cc1cc(O)ccc1O</smiles>

Isozonarol<smiles></smiles>

Figure 8. Chemical structures of hydroquinones and closely related derivatives isolated from Dictyopteris undulata.

Wätjen et al. isolated three polyprenylhydroquinones from the Mediterranean marine sponges Sarcotragus muscarum (Schmidt, 1864) and Ircinia fasciculata (Pallas, 1766), both belonging to the family of the Irciinidae. These compounds were identified as hexa-, hepta- and nonaprenyl-1,4-hydroquinones (Figure 9). They displayed strong antioxidative activity, similar tothat of Trolox, in a TEAC cell-free system, by using ABTS ${ }^{\bullet+}$. Hexaprenylhydroquinone showed cytotoxicity at a low micromolar range $\left(\mathrm{EC}_{50} 2.5 \mu \mathrm{M}\right)$ in H4IIE rat hepatoma cells. All three hydroquinones inhibited the activity of the nuclear factorkappa B in this cell line, with heptaprenylhydroquinone being the most active. Hexaand hepta-prenylhydroquinones showed inhibitory activity against certain protein kinases involved in signal transduction pathways, such as the epidermal growth factor receptor ( $\mathrm{IC}_{50} 3.1$ and $2.4 \mu \mathrm{M}$, respectively). Heptaprenylhydroquinone also inhibited the activity of Src tyrosine kinase, vascular endothelial growth factor receptor 3 , and insulin-like growth factor 1 receptor [18].

Mori et al. isolated four new plastoquinones (2-geranylgeranyl-6-methylbenzoquinones) (Figure 10) from the brown alga Sargassum micracanthum Kützing (Endlicher) (Sargassaceae), which showed radical scavenging effect on $\mathrm{DPPH}^{\bullet}$ and inhibited NADPHdependent lipid peroxidation in rat liver microsomes. Two of them (compounds 10.a and 10.d) showed $\mathrm{IC}_{50}$ values of 2.22 and $1.65 \mu \mathrm{Min}$ lipid peroxidation, respectively, but they had only moderate reducing effect on $\mathrm{DPPH}^{\bullet}$. It is of interest that the absence or presence of an unsaturated cis double bond in the fatty acid ester moiety of compounds 10.c (stearyl) and 10.d (oleyl), respectively, leads toa marked difference in the inhibitory activity. When authors tested the antiproliferative activity of these compounds, they observed that compounds 10.a and 10.d displayed interesting activity against colon 26-L5 cells with $\mathrm{IC}_{50}$ values of 3.52 and $2.43 \mu \mathrm{M}$, respectively, while compound 10.c had only moderate activity $\left(\mathrm{IC}_{50} 25.12 \mu \mathrm{M}\right)$ [19]. 
From the same species, Iwashima et al. isolated two plastoquinones and one new chromene derivative converted from plastoquinones (Figure 10). Two of the plastoquinones (10.b and 10.e), and the chromene (10.f), exhibited significant antioxidant activities, with $\mathrm{IC}_{50}$ values of $0.25,2.34$, and $0.65 \mu \mathrm{M}$, respectively, on lipid peroxidation but a moderate radical reducing effect on $\mathrm{DPPH}^{\bullet}$, with $\mathrm{IC}_{50}$ of 25.68 and $24.98 \mu \mathrm{M}$ for compounds $\mathbf{1 0 . b}$ and 10.f, respectively. The strong antioxidant activity of these compounds might be related to the hydroquinone and phenol moiety, respectively, after their transformation in a stable phenoxyl radical [20].

The fungi of the Genus Ganoderma (Ganodermataceae) have been widely used as traditional Asian medicines for centuries and are gaining attention in Western countries. Phytochemical studies on this genus led to the isolation of hundreds of compounds, including over 380 terpenoids, e.g., ganoderic acids, lucidenic acids, and some meroterpenoids, which showed significant pharmacological activities such as antioxidant, immunomodulatory, and antitumoral properties. From the fruiting bodies of Ganoderma capense (Lloyd) Teng, eight hydorquinone meroterpenoids were isolated and identified as ganocapensins $\mathrm{A}$ and B; fornicin B and E; and ganomycin C, E, F and I (Figure 11).<smiles>CC(C)=CCC(C)CC(C)=CCC(C)C</smiles>

$\left(2^{\prime} E, 6^{\prime} E, 10^{\prime} E, 14^{\prime} E, 18^{\prime} E\right)$-Hexaprenylhydroquinone<smiles>CC(C)=CCC(C)CC(C)=CCC(C)C</smiles>

$\left(2^{\prime} E, 6^{\prime} E, 10^{\prime} E, 14^{\prime} E, 18^{\prime} E, 22^{\prime} E\right)$-Heptaprenylhydroquinone<smiles>CCC(C)=CCC(C)(C)CC=C(C)C</smiles>

$\left(2^{\prime} E, 6^{\prime} E, 10^{\prime} E, 14^{\prime} E, 18^{\prime} E, 22^{\prime} E, 26^{\prime} E, 32^{\prime} E\right)$-Nonaprenylhydroquinone

Figure 9. Chemical structures of hydroquinones isolated from Sarcotragus muscarum. 
<smiles>CC(C)=CCC(C)CC(=O)C(C)(C)O</smiles>

10.a

2-[(2'E,6'E,10'E)-14'-Oxo-15'-hydroxy-tetraprenyl)]-6-methylhydroquinone<smiles>[R20]c1cc(C)c(O)c(CC=C(C)CC(C)C)c1</smiles>

10.b $\mathrm{R}=-\mathrm{H} ; \mathbf{1 0 . c} \mathrm{R}=$-stearyl; 10.d R= -oleyl

2-[(2'E,6'E,10'E)-14',15'-Dihydroxy-tetraprenyl)]-6-methylhydroquinone and its 6-O-acyl fatty derivatives<smiles>CCC(C)=CCC1=CC(=O)C=C(C)C1=O</smiles>

10.e

2-[(2'E,6'E,10'E)-14',15'-Dihydroxy-tetraprenyl)]-6-methylbenzoquinone

$\mathrm{HO}$<smiles>C/C(=C\CC[C@]1(C)C=Cc2cc(C)cc(C)c2O1)CC/C=C(\C)CC[C@@H](O)C(C)(C)O</smiles>

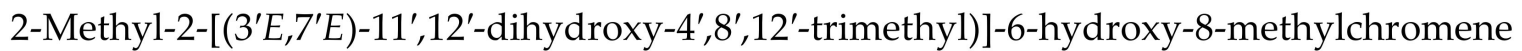

Figure 10. Chemical structures of hydroquinones and related compounds isolated from Sargassum micracanthum.

All of them showed significant antioxidant effects in the $\mathrm{DPPH}^{\bullet}$ radical scavenging assay, with $\mathrm{IC}_{50}$ values of $16-22 \mu \mathrm{M}$. The authors suggested that thein vitro antioxidant property of these aromatic meroterpenoids could be of interest for further research and could provide a theoretical basis to the application of compounds isolated from Ganoderma as anti-aging drugs [21]. 
<smiles>C/C1=C\CCC2=CC(c3cc(O)ccc3O)(OC/C(CO)=C/CC2)OC1=O</smiles>

Ganocapensin A<smiles>CC12CC[C@H](O)C(C)(CC1)Oc1ccc(O)cc1C2</smiles>

Ganocapensin B<smiles>[R3]C(C)=CCC/C(C)=C/CCC([R2])(C(=O)O)C([R])C(=O)c1cc(O)ccc1O</smiles>

Ganomycin E R $\mathrm{R}_{1}=\mathrm{R}_{2}=\mathrm{H}, \mathrm{R}_{3}=-\mathrm{CHO}$; Ganomycin $\mathrm{C} \mathrm{R}_{1}, \mathrm{R}_{2}=$ double bond, $\mathrm{R}_{3}=-\mathrm{CH}_{3}$<smiles>CC(C)=CCC/C(C)=C/CC/C(=C/Cc1cc(O)ccc1O)CO</smiles>

\section{Ganomycin F}<smiles>[R2]CC(C)=CCCC(C)=CCCC1=CC([R7])(c2cc(O)ccc2O)OC1=O</smiles>

Fornicin B R $\mathrm{R}_{1}=-\mathrm{OCH}_{3}, \mathrm{R}_{2}=\mathrm{H}$; Fornicin $\mathrm{E} \mathrm{R}_{1}=-\mathrm{OCH}_{3}, \mathrm{R}_{2}=\mathrm{OH}$; Ganomycin I $\mathrm{R}_{1}=\mathrm{R}_{2}=\mathrm{H}$

Figure 11. Chemical structures of hydroquinones isolated from Ganoderma capense.

\subsection{Other Alkyl-Hydroquinones}

Ammar et al. isolated a new hydroquinone glucoside from the aerial parts of Anagallis monelli L. (Primulaceae). The compound was identified as 2-(O- $\beta$-D-glucopyranosyl)-6methylaminomethyl)hydroxy-hydroquinone and called zinolol (Figure 12). This compound was tested for its antioxidant activity on the ABTS and DPPH tests. Zinolol had its maximal inhibition at a concentration of $3 \mathrm{mM}(98 \%)$ on the ABTS test after 5 min of incubation, although it also acted at low concentrations $(0.09-1.5 \mathrm{mM})$ with inhibition percentages of $70 \%$ to $98 \%$ after $5 \mathrm{~min}$ of incubation, and these values were maintained. The reference compound Trolox produced a similar inhibition ( $98 \%$, at $4 \mathrm{mM}$ after $5 \mathrm{~min}$ of incubation). In the case of the DPPH ${ }^{\bullet}$ scavenging capacity test, the antioxidant activity of zinolol was also $98 \%$ after 30 min of incubation, similar to Trolox (99\% inhibition) in similar conditions 
( $3 \mathrm{mM}$, after $30 \mathrm{~min}$ of incubation). The inhibitory effect of zinolol was concentrationdependent; its antioxidant effect increased from $26 \%(0.09 \mathrm{mM})$ to $97 \%(3 \mathrm{mM})$. This effect was due to the oxidation of hydroquinone skeleton and subsequent formation of the stable form of quinone. As a conclusion, the authors considered that zinolol is an effective antioxidant agent that could be useful for prevention of pathologies in which the free radicals and their oxidative damage are implicated, such as genotoxicity and cancer [22].<smiles>CNCc1cc(O)cc(OC2O[C@H]3C(O)C[C@@H](O)[C@H](O)[C@H]3O2)c1O</smiles>

Figure 12. Chemical structure of zinolol isolated from Anagallis monelli.

Rhus succedanea L. (Anacardiaceae) is another source of hydroquinones. From the lacquer obtained of this plant, Wu et al. [23] isolated three compounds, two of them being new natural compounds, which were identified as: $10^{\prime}(Z), 13^{\prime}(E), 15^{\prime}(E)$-heptadecatrienylhydroquinone (13.a) and $10^{\prime}(Z), 13^{\prime}(E)$-heptadecadienylhydroquinone (13.b), as well as the known compound $10^{\prime}(Z)$-heptadecenylhydroquinone (13.c, Figure 13). All of them were tested in an iron/ascorbate system for establishing the capacity to inhibit peroxide formation in linoleic acid (used as a substrate). The antioxidative effectiveness was established for the three compounds, showing the two new compounds 13.a and 13.b, at 11.7 and $11.6 \mu \mathrm{M}$, respectively, near-complete inhibitory effects similar to the positive control, BHT, at $18.1 \mu \mathrm{M}$. Compound 13.c, at 11,6 $\mu \mathrm{M}$, reached $60 \%$ of the effect of BTH.<smiles>[R]c1cc(O)ccc1O</smiles><smiles>[R]=CCC=CC=CC</smiles>

$10^{\prime}(Z), 13^{\prime}(E), 15^{\prime}(E)$-heptadecatrienylhydroquinone<smiles>CCCC=CCC=CCCCCCCCCCC</smiles>

$10^{\prime}(Z), 13^{\prime}(E)$-heptadecadienylhydroquinone<smiles>CCCCCCC=CCCCCCCCCC</smiles>

10' (Z)-heptadecenylhydroquinone

Figure 13. Chemical structures of hydroquinones isolated from Rhus succedanea.

\section{Interactions with Enzymes, Transcription Factors, and Other Proteins}

Melanin is a natural skin pigment responsible for absorption and skin protection from harmful UV radiation. Tyrosinase plays an important role in melanin synthesis and is the main enzyme involved in the melanogenesis process in mammals and the enzymatic browning of fruits, vegetables, and fungi. Therefore, the search for new and 
potent tyrosinase inhibitors, including those of plant-based natural products, is of interest for application in medicine for the treatment of hyperpigmentation diseases, in cosmetics such as skin-lightening agents, and in the food industry. Several natural or synthetic compounds are used as active constituents of preparations to treat hyperpigmentation but are not completely adequate in terms of effectiveness and safety. In this context, one of the main depigmenting agents like hydroquinone is only available under prescription and banned in cosmetic use. Only a few compounds are currently used for clinical purposes as skin-whitening agents. Arbutin, characterized by its wide distribution in the Ericaceae and Caprifoliaceae families, exhibits anti-melanogenic activity in vitro and in vivo and can be useful in hyperpigmentation therapy [24]. The aqueous extract of Arbutus andrachne L. (Ericaceae) is used topically as skin lightener in some areas of Jordan. The methanol extract of the stems of this species, containing a high concentration of arbutin, exhibited 97\% inhibitory activity against tyrosinase-catalysed oxidation of L-tyrosine [25].

Six new acyl-glucosides of hydroquinone containing different unsaturated linear monoterpenoid esters at the C- $6^{\prime \prime}$ of the sugar moiety, together with the known analogue phlebotrichin (Figure 14), were isolated from the leaves of Viburnum erosum Thunb (Caprifoliaceae). When evaluated for their tyrosinase inhibitory activities, these new derivatives did not exhibit any effect, probably due to the monoterpenoid chain that impedesbinding of tyrosinase enzyme to the compounds. Nevertheless, phlebotrichin still showed moderate effectiveness compared with the positive control arbutin [26].

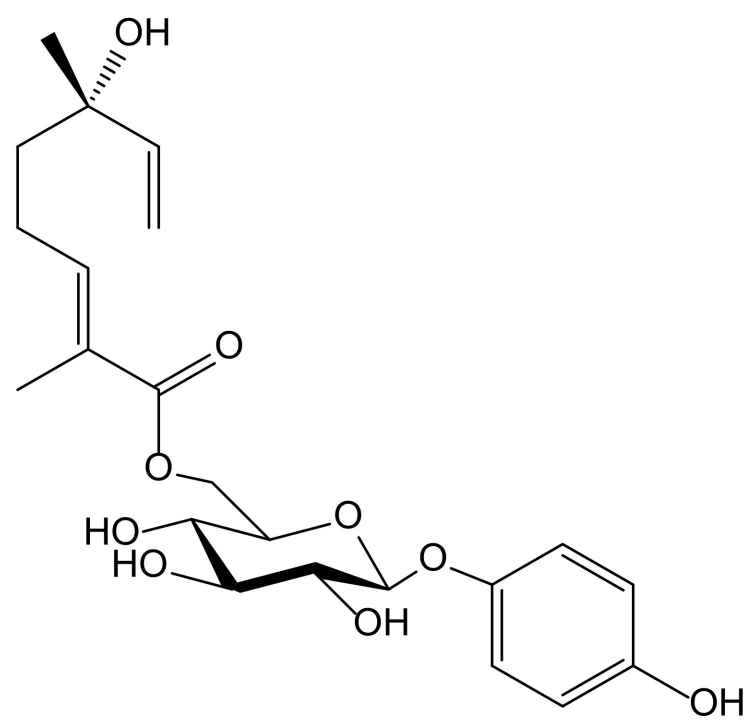

Figure 14. Chemical structure of phlebotrichin from Viburnum erosum.

Marine-derived and plant-pathogenic fungi are considered as a source of bioactive compounds that displayed a variety of pharmacological activities. Endophytic fungi inhabit plant tissues and are significant components of plant micro-ecosystems, altering the quality of the crude drugs through a specific fungus-host interaction since they can affect their host plants by improving their growth, enhancing their robustness, strengthening their tolerance to stress, and stimulating production of secondary metabolites.

Seven new terpenoid hydroquinones produced from the endophytic fungus Pestalotiopsis neglecta (Thüm.) Steyaert (Xylariaceae), strain SCSIO41403, were isolated from a Coelarthrum sp. red alga, collected at the sea coast of southern China. These compounds, bearing a vinyl alkyne, were identified as four ene-yne-hydroquinones, called pestalotioquinols $\mathrm{C}-\mathrm{F}$, and three glycosylated derivatives, the pestalotioquinosides $\mathrm{A}-\mathrm{C}$. The structure of pestalotioquinol $C$, which was quantitatively preponderant amongthe metabolites, was determined as 6(Z)-(2,5-dihydroxyphenyl)-4-methylhex-3-en-5-ynoic acid (Figure 15). 


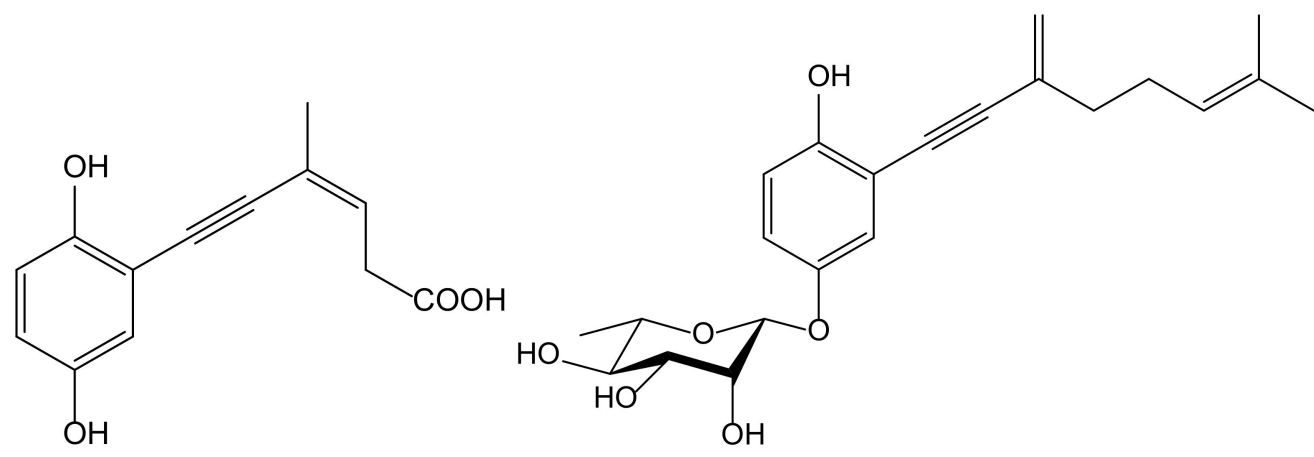

(a)

(b)

Figure 15. Chemical structure of pestalotioquinol $C(\mathbf{a})$ and pestalotioquinoside $C(\mathbf{b})$ isolated from a fermentation broth of Pestalotiopsis neglecta, a fungus endophytic to Coelarthrum sp.

It has been reported that liver $\mathrm{X}$ receptor (LXR) $\alpha$ acts as oxysterol sensor; its agonists represent a feasible approach to control cholesterol efflux, and they are regulators of the reverse cholesterol transport pathway, preventing pathological conditions driven by lipid metabolism dysfunction, such as vascular and metabolic diseases, neurological degeneration, or cancer. The affinity of the abovementioned ene-yne-hydroquinones to the $\mathrm{LXR} \alpha$ was analyzed in vitroand in silico, and the results demonstrated that pestalotioquinoside C (Figure 15) has LXR $\alpha$ modulatory properties. Through binding with the LXR $\alpha$, this glycosylated hydroquinone $(50 \mu \mathrm{M})$ stimulated the transcriptional activity driven by the receptor [27], which resulted in the upregulation of the gene Abca1, a key agent for the transmembrane transport of cholesterol and fatty acid derivatives, by interacting with Apo E and Apo A1 lipoproteins.

Luo et al. isolated seven new meroterpenoids containing a hydroquinone moiety, called ganotheaecolumols E-K, together with nine known compounds from the fruiting bodies of Ganoderma theaecolum, which is used as a substitute for G. lingzhi in the treatment of chronic diseases. The new derivatives, ganotheaecolumol I and K, and the known one, isoganotheaecolumol I (Figure 16), revealed inhibitory effects against cyclooxygenase-2 ( $\mathrm{IC}_{50}$ values between 2.61 to $\left.4.84 \mu \mathrm{M}\right)$ and tyrosine-protein kinase $3\left(\mathrm{IC}_{50}\right.$ values between 3.63 to $15.64 \mu \mathrm{M})[28]$.<smiles>[R]C([R])=CCCC(C)=CCCC(=CC(=O)c1cc(O)ccc1O)C(=O)O</smiles>

Isoganotheaecolumol I $\mathrm{R}_{1}=\mathrm{CH}_{3} \mathrm{R}_{2}=\mathrm{CH}_{2} \mathrm{OH}$; Ganotheaecolumol I $\mathrm{R}_{1}=\mathrm{CH}_{2} \mathrm{OH} \mathrm{R}_{2}=\mathrm{CH}_{3}$<smiles>C/C(=C\CC/C=C(\C)CC/C=C(/CC(=O)c1cc(O)ccc1O)C(=O)O)CO</smiles>

Ganotheaecolumol K

Figure 16. Chemical structures of hydroquinones isolated from Ganoderma theaecolum. 
Previously, Yan et al. [29] isolated a pair of meroterpenoid enantiomers from Ganoderma lucidum (Curtis) P. Karst., which were identified as (+)-lingzhiol and (-)-lingzhiol (Figure 17). Their pharmacological evaluation showed that both compounds at 10 and $30 \mu \mathrm{M}$ significantly inhibited, in a concentration-dependent manner, ROS, collagen IV, fibronectin, and interleukin (IL)-6 overproduction in high-glucose treated mesangial cells. Under such diabetic-like conditions, both principles inhibited at $10 \mu \mathrm{M}$ the transcript levels of collagen IV, fibronectin, and IL-6 but induced Nrf2, which is a key regulator of the cellular defense against electrophilic and oxidative species stress. (-)-Lingzhiol and, to a lesser extent, (+)-lingzhiol inhibited transforming growth factor- $\beta_{1}$-mediated Smad3 phosphorylation but not that of Smad2, in a concentration-dependent manner in rat renal proximal tubular cells NRK-52E. All these findings suggest that both derivatives could have protective effects in kidney diseases.

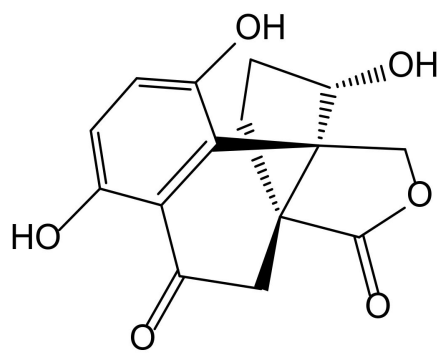

(+)-Lingzhiol

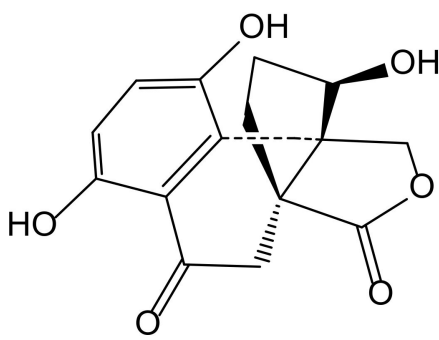

(-)-Lingzhiol

Figure 17. Chemical structures of hydroquinones isolated from Ganoderma lucidum.

Several natural hydroquinones have been reported to be neuroprotective, suggesting that the ability of conversion of a $p$-dihydroxybenzene to a benzoquinone by autooxidation is essential for that activity because such compounds behave like pro-electrophilic compounds. They can activate Nrf2, which induces ARE-dependent expression of detoxifying and antioxidant defense proteins, such as NADPH quinone oxidoreductase 1 (NQO1), glutathione $S$-transferase, and heme oxygenase-1 (HO-1), maintaining the redox homeostasis of the cell.

Sasaki et al. [30] described the neuroprotective effects of a novel abietane-type diterpene $p$-hydroquinone (11,14-dihydroxy-8,11,13-abietatriene) (Figure 18) derived from cryptoquinone (7,11,14-trioxoabieta-8,12-diene) isolated from the bark of Cryptomeria japonica (Thunb. ex L.f.) D. Don (Cupressaceae). It activated, at $5 \mu \mathrm{M}$, the Nrf2/ARE system, inducing $\mathrm{HO}-1$ and NQO1 expression as well as increasing glutathione in the neuronal HT22 cell line from mouse hippocampus, thus protecting neuronal cells from oxidative stress. Cryptoquinone exhibited cytotoxic activity against mouse lymphoid neoplasm cells P388 with an $\mathrm{IC}_{50}$ of $0.26 \mu \mathrm{M}$ and modest antifungal activity against Pyricularia orizae and Alternaria alternata [31].

Previously, Sasaki et al. [32] demonstrated that strongylophorine-8 (Figure 19), a hydroquinone triterpene pro-electrophilic compound from the marine sponge Petrosia (Strongylophora) corticata (Wilson, 1925) (Petrosiidae), protected neuronal cells from oxidative stress by activating the Nrf2/ ARE pathway, inducing phase 2 enzymes and increasing glutathione. However, its protective effects $(4.1 \mu \mathrm{M})$ were very close to cytotoxic effects $(14.24 \mu \mathrm{M})$, suggesting that it would not be adequate for further in vivo applications.

Kanno et al. isolated the pestalotioquinols A and B (Figure 20) from a fungal culture broth of Pestalotiopsis microspora (Speg.) G.C. Zhao and N. Li. Pretreatment with 1-3 $\mu \mathrm{M}$ of pestalotioquinols $\mathrm{A}$ and $\mathrm{B}$ prevented the death of nerve growth factor-differentiated neuronal PC12 cells provoked by peroxynitrite $\left(\mathrm{ONOO}^{-}\right)$, and the protective activity subsisted even after removing the compounds, showing neuroprotective effects [33]. 
<smiles>CC(C)C1=CC(=O)C2=C(C(=O)CC3C(C)(C)CCC[C@@]23C)C1=O</smiles>

(a)<smiles>CC(C)c1cc(O)c2c(c1O)CCC1C(C)(C)CCC[C@@]21C</smiles>

(b)

Figure 18. Chemical structures of cryptoquinone (a), isolated from Cryptomeria japonica, and of the synthetic hydroquinone, 11,14-dihydroxy-8,11,13-abietatriene (b).<smiles>CC12CCC34COC(=O)CC3(C1)C1CC[C@@](C)(O)C(Cc3cc(O)ccc3O)[C@@]4(C)CCC12</smiles>

Figure 19. Chemical structure of strongylophorine-8, isolated from Petrosia corticata.<smiles>C=C(C#Cc1cc(O)ccc1O)CCC=C(C)CC[C@@H](O)C(C)(C)O</smiles>

Pestalotioquinol A<smiles>C=C(C#Cc1cc(O)ccc1O)CCC(O)C(C)(C)CCC=C(C)C</smiles>

\section{Pestalotioquinol B}

Figure 20. Chemical structures of hydroquinones isolated from Pestalotiopsis microspora.

From the colonial tunicate Amaroucium multiplicatum (Sluiter 1909, Polyclinidae) collected in central to southern Japan seashore, Sato et al. [34] isolated geranylhydroquinone and two new closely related hydroxyl derivatives. The novel compounds were identified as $3^{\prime}$-hydroxy-1',2'-dihydro-diprenylhydroquinone, (1E)-3'-hydroxy-diprenylhydroquinone, and $\left(2^{\prime} E\right.$ )-diprenylhydroquinone (Figure 21). These compounds were tested for their activity on soybean 15-lipoxygenase (15-LOX) and on lipid peroxide formation induced in rat liver microsomes by ferrous sulphate/cysteine. The 6-monoenyl derivative showed an 
inhibitory effect $\left(\mathrm{IC}_{50} 11.35 \mu \mathrm{M}\right)$ in the latter one. Both new hydroquinones exhibited $\mathrm{IC}_{50}$ values of $1.14-3.78 \mu \mathrm{M}$ in the former system, while only geranylhydroquinone produced $\mathrm{IC}_{50}$ values within the range $0.3-1.5 \mu \mathrm{M}$ in both models. All three hydroquinones were more potent antioxidants than $\alpha$-tocopherol acetate $\left(\mathrm{IC}_{50}>21.15 \mu \mathrm{M}\right)$.<smiles>CC(C)=CCCC(C)(O)CCc1cc(O)ccc1O</smiles>

3'-Hydroxy-1',2'-dihydro-diprenylhydroquinone<smiles>CC(C)=CCCC(C)(O)/C=C/c1cc(O)ccc1O</smiles>

(1E)-3'-Hydroxy-diprenylhydroquinone<smiles>CC(C)=CCC/C(C)=C/Cc1cc(O)ccc1O</smiles>

(2'E)-Diprenylhydroquinone

Figure 21. Chemical structures of hydroquinones isolated from Amaroucium multiplicatum.

Three new hydroquinone glucosides isolated from Phagnalon rupestre (L.) DC. (Compositae) were evaluated for their inhibitory effects on the nitration and oxidation of biomolecules induced by $\mathrm{ONOO}^{-}$. These compounds, 1-O- $\beta$-glucopyranosyl-2-prenylhydroquinone, 1-O- $\beta$ glucopyranosyl-2-(3'-hydroxy)-prenylhydroquinone, and 1-O-(4" -O-caffeoyl)- $\beta$-glucopyranosyl-2-prenylhydroquinone (Figure 22), inhibited the nitration of tyrosine by $79 \%, 49 \%$, and $30 \%$, respectively, at $100 \mu \mathrm{M}$, and the first one exhibited the highest potency (IC 50 $40 \mu \mathrm{M})$. The benzene ring was susceptible to nitration, thus preventing that of tyrosine, but the presence of the hydroxymethyl group at the end of isoprenyl chain in the second compound, and a caffeoyl moiety in the third one, were unfavorable for such mechanism. However, all three compounds protected against the oxidation of dihydrorhodamine at $25 \mu \mathrm{M}$ mediated by $\mathrm{ONOO}^{-}$, with caffeoyl derivative being the most active $\left(\mathrm{IC}_{50} 9.1 \mu \mathrm{M}\right)$, as expected due to the presence of an ortho-dihydroxyl group [35]. The isoprenyl hydroquinone glucoside was further studied for its inhibitory activity against the protein carbonylationon caused by phorbol ester (12-O-tetradecanoylphorbol-13-acetate, TPA)induced leukocyte oxidative burst, and on two cell-free models such as bovine serum albumin carbonylation caused by hypochlorite $\left(\mathrm{OCl}^{-}\right)$or $\mathrm{ONOO}^{-}$. In the latter one, the behavior of the compound on protein carbonylation was in line with its effect on tyrosine nitration described above. As expected, it was active in the presence of reactive nitrogen species and exhibited an $\mathrm{IC}_{50}$ value of $86.3 \mu \mathrm{M}$ when the oxidation of protein was driven by $\mathrm{ONOO}^{-}$, but it showed no activity when the reaction was caused by $\mathrm{OCl}^{-}$. In the 
case of the respiratory burst of leukocytes stimulated with TPA, isoprenylhydroquinone glucoside was barely active, although it almost inhibited the effect at the high concentration of $100 \mu \mathrm{M}$ [36].

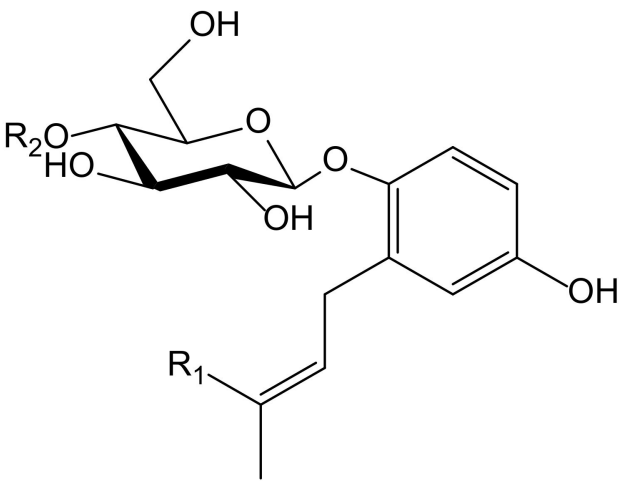

$\begin{array}{lcc} & \mathrm{R}_{1} & \mathrm{R}_{2} \\ \text { 1-O- } \beta \text {-Glucopyranosyl-2-prenylhydroquinone } & \mathrm{CH}_{3} & \mathrm{H} \\ \text { 1-O- } \beta \text {-Glucopyranosyl-2-(3'-hydroxy)prenylhydroquinone } & \mathrm{CH}_{2} \mathrm{OH} & \mathrm{H} \\ \text { 1-O-(4"-O-Caffeoyl)- } \beta \text {-glucopyranosyl-2-(3'-hydroxy)prenylhydroquinone } & \mathrm{CH}_{3} & \text { caffeoyl }\end{array}$

Figure 22. Chemical structures of hydroquinones isolated from Phagnalon rupestre.

\section{Structure/Activity Relationship}

To study the possible relationship between the chemical structure and the antioxidant activity, it is feasible to consider essentially the models included in Section 2 since, even with their deficiencies from a biological point of view, the methods applied are quite homogeneous and the experimental conditions controlled.For such a purpose, according to the reviewed literature, three determinations are definitely the most important: scavenging of $\mathrm{DPPH}^{\bullet}$, scavenging of $\mathrm{ABTS}^{\bullet+}$, and inhibition of lipid peroxidation. In the first case, the $\mathrm{IC}_{50}$ values of the different compounds ranged from $15 \mu \mathrm{M}$ to $75 \mu \mathrm{M}$, with the most potent being simple hydroquinone and the hydroquinone meroterpenoids from Ganoderma capense, which are indeed quite different from each other. Regarding the inactivation of $\mathrm{ABTS}^{\bullet+}$, only a few compounds have been described, although their potency $(0.3-5.0 \mu \mathrm{M})$ is higher than that reported for the products assayed in the DPPH test. In both free radical scavenging systems, the lowest potency corresponds to the methylamine, zinolol. In the field of lipid peroxidation, numerous compounds with potency between 2.0 and $20.0 \mu \mathrm{M}$ have been described, possessing in the vast majority of cases an alkyl, mostly prenyl, chain. A far from exhaustive comparison with some plant phenolics compounds [37] indicates that the reported hydroquinones have potencies in the range of well-known flavonols or catechins. According to the available data, it has not been possible to find additional criteria that could support a firm structural relationship with pharmacological potency.

\section{Conclusions}

Even for the least passionate student of the chemistry of natural products, it is very relevant, even magnificent, to observe the contrast between the enormous phylogenetic dispersion of the origin of raw materials, and the repetition of structural motifs. This occurs in a very obvious way with the wide range of antioxidant poly-isoprenylbenzenes and poly-isoprenylquinones. Probably because hydroquinones have relatively little value as active principles in medicinal plants, most reports of their antioxidant activity lack a direct connection to potential therapeutic value. This is because many articles, otherwise very interesting from a chemical point of view, contain only a fairly brief account of the possible bioactivity of the compounds studied. However, some lines of pharmacological progress are easily perceivable in the literature analyzed. As an example, the neuroprotective activity of 
zonarol and analogs from Dictyopteris, based on the stimulation of the Nrf2/ARE pathway, deserves special mention. Moreover, the uniqueness of the chemistry of aromatic ene-ynes pestaloquinol analogs, together with their agonistic interaction with LXR $\alpha$, proved to be of high value for a screening in the pharmacology of atherosclerosis. Finally, the dissection of indiscriminate antioxidant activity from selective effects on tyrosine nitration or protein carbonylation, as occurs in the principles of Phagnalon, presents interesting possibilities in the control of post-translational protein modification habitually appearing in chronic inflammatory diseases.

Funding: This research received no external funding.

Conflicts of Interest: The authors declare no conflict of interest.

\section{Abbreviations}

Acronyms, symbols and formulae.

$\begin{array}{ll}\text { ABAP } & \text { 2,2'-azobis(2-amidinopropane) } \\ \text { ABTS } & \text { 2,2'-azinobis(3-ethylbenzothiazoline-6-sulfonic acid) } \\ \text { BHT } & \text { butylated hydroxytoluene } \\ \text { DPPH } & \text { 1,1-diphenyl-2-picrylhydrazyl } \\ \text { EC } 50 & \text { half maximal effective concentration } \\ \text { EDTA } & \text { ethylenediaminetetraacetic acid } \\ \text { FRAP } & \text { ferric reducing antioxidant power } \\ \text { HO-1 } & \text { heme oxygenase-1 } \\ \text { IC } 50 & \text { half maximal inhibitory concentration } \\ \text { IL } & \text { interleukin } \\ \text { 15-LOX } & \text { 15-lipoxygenase } \\ \text { LXR } \alpha & \text { liver X receptor } \alpha \\ \text { NQO1 } & \text { NADPH quinone oxidoreductase 1 } \\ \text { Nrf2/ARE } & \text { Nuclear factor-erythroid 2-related factor 2/antioxidant-responsive element } \\ \mathrm{O}^{2}- & \text { superoxide anion } \\ \text { OCl } & \\ \text { ONOO } & \text { hypochlorite anion } \\ \text { PHB } & \text { peroxynitrite anion } \\ \text { ROS } & \text { p-hydroxybenzoate } \\ \text { SC } & \text { reactive oxygen species } \\ \text { TBARS } & \text { scavenger concentration 50\% } \\ \text { TEAC } & \text { thiobarbituric acid reacting species } \\ \text { Trolox } & \text { Trolox equivalent antioxidant capacity } \\ & \text { 6-hydroxy-2,5,7,8-tetramethylchroman-2-carboxylic acid }\end{array}$

\section{References}

1. Shang, Y.; Wei, W.; Zhang, P.; Ye, B.C. Engineering Yarrowia lipolytica for enhanced production of arbutin. J. Agric. Food Chem. 2020, 68, 1364-1372. [CrossRef] [PubMed]

2. Smith, T.E. Biogenetic relationships of bioactive sponge merotriterpenoids. Mar. Drugs 2017, 15, 285. [CrossRef]

3. Lenaz, G. The mitochondrial production of reactive oxygen species: Mechanisms and implications in human pathology. IUBMB Life 2001, 52, 159-164. [CrossRef] [PubMed]

4. Crane, F.L.; Hatefi, Y.; Lester, R.L.; Widmer, C. Isolation of a quinone from beef heart mitochondria. Biochim. Biophys. Acta 1957, 25, 220-221. [CrossRef]

5. Ohsugi, M.; Fan, W.; Hase, K.; Xiong, Q.; Tezuka, Y.; Komatsu, K.; Namba, T.; Saitoh, T.; Tazawa, K.; Kadot, S. Active-oxygen scavenging activity of traditional nourishing-tonic herbal medicines and active constituents of Rhodiola sacra. J. Ethnopharmacol. 1999, 67, 111-119. [CrossRef]

6. $\quad$ Erenler, R.; Sen, O.; Aksit, H.; Demirtas, I.; Yaglioglu, A.S.; Elmastas, M.; Telci, İ. Isolation and identification of chemical constituents from Origanum majorana and investigation of antiproliferative and antioxidant activities. J. Sci. Food Agric. 2016, 96, 822-836. [CrossRef] [PubMed]

7. Dong, L.M.; Ji, X.C.; Luo, Q.W.; Zhang, Q.; Luo, B.; Liu, W.B.; Zhang, X.; Xu, Q.L.; Tan, J.W. Phenolics from Mikania micrantha and their antioxidant activity. Molecules 2017, 22, 1140. [CrossRef] 
8. Chantarudee, A.; Phuwapraisirisan, P.; Kimura, K.; Okuyama, M.; Mori, H.; Kimura, A.; Chanchao, C. Chemical constituents and free radical scavenging activity of corn pollen collected from Apis mellifera hives compared to floral corn pollen at Nan, Thailand. BMC Complement. Altern. Med. 2012, 12, 45. [CrossRef]

9. Zhokhov, S.S.; Jastrebova, J.A.; Kenne, L.; Broberg, A. Antioxidant hydroquinones substituted by beta-1,6-linked oligosaccharides in wheat germ. J. Nat. Prod. 2009, 72, 656-661. [CrossRef]

10. Adisa, R.A.; Olorunsogo, O.O. Robustaside B and para hydroxyphenol: Phenolic and antioxidant compounds purified from Cnestis ferruginea DC. induced membrane permeability transition in rat liver mitochondria. Mol. Med. Rep. 2013, 8, 1493-1498. [CrossRef]

11. Karioti, A.; Milošević-Ifantis, T.; Pachopos, N.; Niryiannaki, N.; Hadjipavlou-Litina, D.; Skaltsa, H. Antioxidant, anti-inflammatory potential and chemical constituents of Origanum dubium Boiss., growing wild in Cyprus. J. Enzyme Inhib. Med. Chem. 2015, 30, 38-43. [CrossRef] [PubMed]

12. Yamaguchi, L.F.; Lago, J.H.G.; Tanizaki, T.M.; Mascio, P.D.; Kato, M.J. Antioxidant activity of prenylated hydroquinone and benzoic acid derivatives from Piper crassinervium Kunth. Phytochemistry 2006, 67, 1838-1843. [CrossRef] [PubMed]

13. Fish, K.M.; Böhm, V.; Wright, A.D.; König, G.M. Antioxidative meroterpenoids from the brown alga Cystoseira crinita. J. Nat. Prod. 2003, 66, 968-975. [CrossRef] [PubMed]

14. Kamagai, M.; Nishikawa, K.; Matsuura, H.; Umezawa, T.; Matsuda, F.; Okino, T. Antioxidants from the brown alga Dictyopteris undulata. Molecules 2018, 23, 1214. [CrossRef]

15. Yamada, S.; Koyama, T.; Noguchi, H.; Ueda, Y.; Kitsuyama, R.; Shimizu, H.; Tanimoto, A.; Wang, K.Y.; Nawata, A.; Nakayama, T.; et al. Marine hydroquinone zonarol prevents inflammation and apoptosis in dextran sulfate sodium-induced mice ulcerative colitis. PLoS ONE 2014, 9, e113509. [CrossRef]

16. Nakanishi, I.; Ohkubo, K.; Ogawa, Y.; Matsumoto, K.I.; Ozawa, T.; Fukuzumi, S. Aluminium ion-promoted radical-scavenging reaction of methylated hydroquinone derivatives. Org. Biomol. Chem. 2016, 14, 7956-7961. [CrossRef]

17. Shimizu, H.; Koyama, T.; Yamada, S.; Lipton, S.A.; Satoh, T. Zonarol, a sesquiterpene from the brown algae Dictyopteris undulata provides neuroprotection by activating the Nrf2/ARE pathway. Biochem. Biophys. Res. Commun. 2015, 457, 718-722. [CrossRef]

18. Wätjen, W.; Putzb, A.; Chovoloua, Y.; Kampköttera, A.; Totzkec, F.; Kubbutatc, M.H.G.; Prokschb, P.; Konuklugild, B. Hexa-, hepta- and nonaprenylhydroquinones isolated from marine sponges Sarcotragus muscarum and Ircinia fasciculata inhibit NF- $\mathrm{B}$ signalling in H4IIE cells. J. Pharm. Pharmacol. 2009, 61, 919-924. [CrossRef]

19. Mori, J.; Iwashima, M.; Wakasugi, H.; Saito, H.; Matsunaga, T.; Ogasawara, M.; Takahashi, S.; Suzuki, H.; Hayashi, T. New plastoquinones isolated from the brown alga, Sargassum micracanthum. Chem. Pharm. Bull. 2005, 53, 1159-1163. [CrossRef]

20. Iwashima, M.; Mori, J.; Ting, X.; Matsunaga, T.; Hayashi, K.; Shinoda, D.; Saito, H.; Sankawa, U.; Hayashi, T. Antioxidant and antiviral activities of plastoquinones from the brown alga Sargassum micracanthum, and a new chromene derivative converted from the plastoquinones. Biol. Pharm. Bull. 2005, 28, 374-377. [CrossRef]

21. Peng, X.; Li, L.; Wang, X.; Zhu, G.; Li, Z.; Qiu, M. Antioxidant farnesylated hydroquinones from Ganoderma capense. Fitoterapia 2016, 111, 18-23. [CrossRef]

22. Ammar, S.; Mahjoub, M.A.; Charfi, N.; Skandarani, I.; Chekir-Ghedira, L.; Mighri, Z. Mutagenic, antimutagenic and antioxidant activities of a new class of $\beta$-glucoside hydroxyhydroquinone from Anagallis monelli growing in Tunisia. Chem. Pharm. Bull. 2007, 55, 385-388. [CrossRef]

23. Wu, P.L.; Lin, S.B.; Huang, C.P.; Chiou, R.Y.Y. Antioxidative and cytotoxic compounds extracted from the sap of Rhus succedanea. J. Nat. Prod. 2002, 65, 1719-1721. [CrossRef]

24. Migas, P.; Krauze-Baranowska, M. The significance of arbutin and its derivatives in therapy and cosmetics. Phytochem. Lett. 2015, 13, 35-40. [CrossRef]

25. Issa, R.A.; Afifi, F.U.; Amor, B.I. Studying the anti-tyrosinase effect of Arbutus andrachne L. extracts. Int. J. Cosmet. Sci. 2008, 30, $271-276$. [CrossRef]

26. Park, J.; Lee, J.; Jang, H.S.; Jeong, B.; Choi, S.Y.; Kim, J.; Kwon, Y.S.; Yang, H. $\alpha$-Glucosidic hydroquinone derivatives from Viburnum erosum. Phytochemistry 2021, 187, 112782. [CrossRef] [PubMed]

27. Wang, J.; Liang, Z.; Li, K.; Yang, B.; Liu, Y.; Fang, W.; Tang, L.; Zhou, X. Ene-yne hydroquinones from a marine-derived strain of the fungus Pestalotiopsis neglecta with effects on liver X receptor alpha. J. Nat. Prod. 2020, 83, 1258-1264. [CrossRef] [PubMed]

28. Luo, Q.; Li, M.K.; Luo, J.F.; Tu, Z.C.; Cheng, Y.X. COX-2 and JAK3 inhibitory meroterpenoids from the mushroom Ganoderma theaecolum. Tetrahedron 2018, 74, 4259-4265. [CrossRef]

29. Yan, Y.M.; Ai, J.; Zhou, L.L.; Chung, A.C.K.; Li, R.; Nie, J.; Fang, P.; Wang, X.L.; Luo, J.; Hu, Q.; et al. Lingzhiols, unprecedented rotary door-shaped meroterpenoids as potent and selective inhibitors of p-Smad3 from Ganoderma lucidum. Org. Lett. 2013, 15, 5488-5491. [CrossRef] [PubMed]

30. Sasaki, S.; Tozawa, T.; Sugamoto, K.; Matsushita, Y.; Satoh, T. A novel diterpene para-hydroquinone compound derived from cryptoquinone protects neuronal cells against oxidative stress and activates the Nrf2/ARE pathway. Neurosci. Lett. 2013, 548, 132-136. [CrossRef]

31. Kofujita, H.; Ota, M.; Takahashi, K.; Kawai, Y.; Hayashi, Y. A diterpene quinone from the bark of Cryptomeria japonica. Phytochemistry 2002, 61, 895-898. [CrossRef]

32. Sasaki, S.; Tozawa, T.; van Wagoner, R.M.; Ireland, C.M.; Harper, M.K.; Satoh, T. Strongylophorine-8, a pro-electrophilic compound from the marine sponge Petrosia (Strongylophora) corticata, provides neuroprotection through Nrf2/ARE pathway. Biochem. Biophys. Res. Commun. 2011, 415, 6-10. [CrossRef] [PubMed] 
33. Kanno, K.; Tsurukawa, Y.; Kamisuki, S.; Shibasaki, H.; Iguchi, K.; Murakami, H.; Uchiyama, J.; Kuramochi, K.J. Novel neuroprotective hydroquinones with a vinyl alkyne from the fungus, Pestalotiopsis microspora. J. Antibiot. 2019, 72, 793-799. [CrossRef] [PubMed]

34. Sato, A.; Shindo, T.; Kasanuki, N.; Hasegawa, K. Antioxidant metabolites from the tunicate Amaroucium multiplicatum. J. Nat. Prod. 1989, 52, 975-981. [CrossRef]

35. Olmos, A.; Máñez, S.; Giner, R.M.; Recio, M.C.; Ríos, J.L. Isoprenylhydroquinone glucoside: A new non-antioxidant inhibitor of peroxynitrite-mediated tyrosine nitration. Nitric Oxide 2005, 12, 54-60. [CrossRef] [PubMed]

36. Marín, M.; Giner, R.M.; Recio, M.C.; Máñez, S. Phenylpropanoid and phenylisoprenoid metabolites from Asteraceae species as inhibitors of protein carbonylation. Phytochemistry 2011, 72, 1821-1825. [CrossRef]

37. Chen, X.; Ahn, D.U. Antioxidant activities of six natural phenolics against lipid oxidation induced by $\mathrm{Fe}^{2+}$ or ultraviolet light. J. Am. Oil Chem. Soc. 1998, 75, 1717-1721. [CrossRef] 